\title{
Evaluation Study: Does The Sharia Supervisory Board Have A Direct Effect on Profitability?
}

\author{
Hasan Mukhibad ${ }^{1}$, Indah Anisykurlillah ${ }^{2}$ \\ Program Studi Akuntansi, Fakultas Ekonomi, Universitas Negeri Semarang.
}

Submitted: 8 April 2020, Accepted: 24 June 2020, Published: 28 June 2020

\begin{abstract}
Previous studies have indicated a complex relationship between the total Sharia Supervisory Board (SSB) members and profitability. Therefore, this study suspects that financing products and bank fundraising mediate the relationship between SSB and ROA. SSB can provide consultation and supervision on the implementation of bank products. Data were obtained from 12 Islamic commercial banks in Indonesia with a 10-year observation period (20092018). Data were analyzed using fixed and random effect models and path analysis. The results showed that the total SSB members and their expertise did not have a direct effect on ROA. However, it has an effect on financing and none on Investment Account Holders (IAH) funds. The results also showed that financing proved to be a mediating variable on the effect between the total and expertise of SSB members towards ROA. The IAH fund is the mediating variable on the effect between the total SSB members towards ROA, with no proven relationship. Therefore, it can be concluded that SSB has an indirect effect on ROA by strengthening the financing and bank fundraising quality. Consultation and supervision carried out by SSB on the implementation of IAH financing and fundraising, has proved to have an impact on improving bank profitability.
\end{abstract}

Keywords: number of members, expertise of the sharia supervisory board, financing, investment account holders, Islamic bank products. 


\section{INTRODUCTION}

According to law number 21 of 2008, Islamic banks raise, distribute, and channel funds using Sharia principles. However, SSB is used to guarantee that the bank has complied with Sharia law. Law Number 21 of 2008 stated that SSB is mandated to provide advice and recommendation to directors and supervise banking activities to comply with Sharia Principles. Similar take was also conveyed by the Accounting and Auditing Organization for Islamic Financial Institutions (AAOIFI) as follows:

"The Shariah Supervisory Board is entrusted with directing, reviewing, and supervising Islamic financial institutions' activities. The fatwas (legal opinions) and Board ruling needs to be binding."

The two regulations show that SSB has a duty to guarantee that Sharia banks are operated in accordance with Sharia rules:

Furthermore, the bank's annual report is also in line with the same statement, as follows:

"The Sharia Supervisory Board supervised the Bank activities by analyzing the reports submitted and requested by the Directors. This is in addition to implementing the internal audit and compliance functions to determine the quality of the Sharia Principles implementation for fundraising and distribution activities in Bank."

"The Sharia Supervisory Board, as an independent party, is entrusted to maintain Bank's compliance with sharia aspects through the periodic conduction of onsite supervision to ensure sharia compliance in the Bank's operations. Furthermore, SSB also reviews the issued products through contracting and operation "(Annual Report of Bank Muamalat, 2018.

Based on these rules and excerpts of the report prepared by the Islamic banks, it is believed that SSB's main duty is fundraising, distributing, and service products in accordance with Sharia. This compliance is needed to ensure that customers get bank services free of interest, gharar, and maysir.

However, several previous studies found that SSB does not only impact on Shariah law bank compliance, it also improves profitability (see Almutairi \& Quttainah, 2017; Nomran, Haron, \& Hassan, 2018; Rahayu, Rasyid, \& Sabir, 2019; Mukhibad \& Khafid, 2018; Farag, Mallin, \& Ow-yong, 2018), and social performance (Rahman \& Bukair, 2013; Fitriyah \& Oktaviana, 2007; Almutairi \& Quttainah, 2016; Farag, Mallin, Ow-Yong, 2014; Indrawaty \& Wardayati, 2016). Furthermore, studies have also provided evidence that SSB plays a positive role in the quality of financial statements (Hamdi \& Zarai, 2014; Mersni \& Othman, 2016) 
and risk disclosures(Neifar \& Jarboui, 2018;Dignah, Latiff, \& Rahman, 2012; 'Srairi; 2018).

In accordance with the SSB duty, the research findings concluded that its role bank's performance is directly less rational. This is because it is not aligned with the SSB function, which emphasizes more on Shariah compliance. According to law No. 21 of 2008, the Sharia law is a fatwa issued by the National Sharia Board (NSB). This means that the Sharia bank principles are a product that has implemented an NSB fatwa.

Therefore, there are inconsistencies associated with this law due to the lack of rationality. The first study provides empirical evidence on the total SBB members, which is one of the measures used to explain the role of SSB, has a positive effect on profitability as measured by ROA (Almutairi \& Quttainah, 2017; Nomran, Haron, \& Hassan, 2018; Farag, Mallin, \& Ow-Yong, 2018; Mukhibad \& Khafid, 2018). However, Hakimi, Rachdi, Mokni, and Hssini (2018); Ardana (2019); Grassa and Matoussi, (2014) alsoMollah and Zaman (2015) stated that the total SBB members do not have a positive effect on ROA. Another indicator used to measure profitability is ROE. According to Hakimi et al. (2018); Grassa and Matoussi (2014) also Mollah and Zaman (2015), there are no relationships between the total SBB members with ROE. Furthermore, Almutairi and Quttainah (2017); Nomran et al. (2018); and Farag, Mallin, and Ow-Yong (2018) reported that the total SBB had a positive effect on ROE.

Therefore, SSB has an inconsistent relationship with performance and an essential role in evaluating and providing services to management regarding Sharia compliance with bank products. This study estimates that the relationship between SSB and profitability is not direct, but by increasing or decreasing bank products. This is because SSB has full authority to reject products that are not compliant with Sharia (Alsartawi, 2019). Mohammed and Muhammed (2017) stated that SSB is one of the bank's stakeholders, and their decision tends to affect the acceptance of one product over another. The decision is debated at the director's board and internal audits levels. Products that obtain a halal guarantee from SSB increases customer confidence to use and re-use the product. It means that the increase in the number of products intervenes on the relationship between the total SBB and profitability.

The total SBB members and SSB expertise are used to test the finance, economics, and accounting sectors. Banks with many SSB members tend to increase supervision and consulting services provided to management. Furthermore, it allows each member to have different backgrounds, experiences, expertise, and considerations, thereby increasing the quality of the strategic decisions taken by SSB (Almutairi \& Quttainah, 2017). Subsequently, SSB's expertise measured by educational background is a factor in carrying out their duties and further improves performance(Grassa, 2016). 


\section{Hypothesis Development}

SSB is one of the independent boards tasked to ensure that Islamic banks comply with Sharia laws in their business transactions. Islamic banks stand because the Muslim community needs those that want to use banking products without interest ( $r i b a)$, gharar, and maysir, which are included as forbidden transactions in Islam. Interest is a common transaction in conventional banks. Therefore, compliance with Sharia law is the main difference with Islamic banks.

In order to carry out this task, SSB functions as a consultant for other boards and as an auditor. This consulting service is provided by SSB when the bank issue a new product. Furthermore, this board has to certify Sharia permitted financial instruments and products (Farag, Mallin, \& Ow-Yong, 2018). Due to intense competition, banks always evaluate, improve, and publish new products rapidly. However, before launching any new product, SSB is consulted and approved in compliance with Islamic law. In providing this consultation, expertise in Islamic law, economics, finance, or accounting is required (Nomran et al., 2018). SSB, with a Sharia educational background, including Islamic finance and contemporary finance, improves decision making (Almutairi \& Quttainah, 2017). Sometimes, this board is involved in corporate strategic decisions. Therefore, banks with large SSBs tend to produce better outcomes. Nomran and Haron (2020) stated that management decision in establishing Islamic banks is limited by SSB that reject proposals that are based on sharia principles. The main functions of a bank are related to fundraising and distribution. Therefore, the following hypothesis is developed:

H1a: The total SBB member has a positive effect on third party funds.

$\mathrm{H} 1 \mathrm{~b}$ : The total SBB member has a positive effect on financing.

SSB acts as a consultant and an internal auditor (Garas, 2010; Farook, Hassan, \& Lanis, 2011; Alsartawi, 2019). This board needs to review all contracts, agreements, products, and financial activities of banks to ensure they comply with Islamic rules and principles (Rahman \& Bukair, 2013). Furthermore, SSB members with financial knowledge and experience need to conduct their responsibilities more effectively (Ghayad, 2008).

This study considers that the relationship between SSB attributes and ROA/ROE is indirect, with the ability to credit and deposit funds. SSB tends to guarantee and provide consulting services for bank products through the collection, fundraising, and distribution of funds. SSB justifies a product submitted by the director, which tends to analyze its similarity with the transaction in accordance with the NSB fatwa. Therefore, to carry out this responsibility, the board requires an understanding of the economic, finance, and accounting fields. Therefore, the hypotheses are as follows: 
H2a: Sharia supervisory board expertise in economics, finance, and accounting has a positive effect on third party funds.

$\mathrm{H} 2 \mathrm{~b}$ : Sharia supervisory board expertise in economics, finance, and accounting has a positive effect on financing.

Banks are intermediary institutions between customers and funds. Customers with excess funds are collected by banks through various savings products with a wadiah or mudharabah contract and distributed in the form of finance. The amount of funds raised by the bank increases its ability to provide financing as its main income source. Therefore, there is a tendency that the amount of deposit funds increases bank income. It is assumed that with each additional fundraised, the bank is able to channel or distribute funds. However, assuming this assumption does not occur, then an increase in deposit funds causes a decrease in bank profitability. However, studies on banks in Indonesia show that third party funds (DPK) have a positive effect on ROA(Sari \& Murni, 2016; Kinanti \& Purwohandoko, 2017; Kassem \& Sakr, 2018).

H3: The ratio of third party funds has a significant effect on profitability.

The main income of Islamic banks is financing, which is channeled to customers. In Islamic banks, many contracts are used in financing distribution, such as mudharabah, musyarakah, murabahah, and ijarah. However, large financing increases bad credit with an impact on profitability. This means that caution is needed in channeling financing to prevent inconsistencies. However, Sari and Murni (2016); Kinanti and Purwohandoko (2017); and Kassem and Sakr (2018) stated that loan to the ratio of third party funds has a positive effect on ROA. More specifically, Dang (2019) reported that an increase in loans had a positive effect on profitability. However, Wang and Wang (2014) identified that large profitability occurs when the loan ratio is low.

H4: Financing has a positive effect on profitability

Almutairi and Quttainah (2017); Nomran et al. (2018); Rahayu, Rasyid, and Sabir (2019); Mukhibad and Khafid (2018); and Farag et al. (2018) stated that SSB affects bank profitability. However, this research stated that the relationship between SSB and profitability is by increasing or decreasing the products offered by banks. It means that the effect between SSB and profitability is indirect because the SSB's main task is to guarantee that the products offered by banks are in accordance with Sharia. Evaluation of product compatibility with Sharia is carried out before the product is introduced to the customer (consultant service) when the contract is enacted (audit service). New product launches are canceled, assuming SSB believes that it is not Shariah-compliant. Therefore, the following hypotheses were developed: H5a: Financing distributed by banks mediates the relationship between the total SBB and 
profitability.

H5b: Third-party funds raised by banks mediate the relationship between the total SBB and profitability.

H5c: Financing distributed by banks mediates the relationship between SSB expertise and profitability.

H5d: Third-party funds raised by banks mediate the relationship between SSB expertise and profitability.

\section{METHOD}

This study uses 12 Islamic commercial banks in Indonesia with a 10-year observation period (2009-2018). Data were analyzed through panel regression and path analysis. This study uses FEM and REM to answer hypotheses 1 through 4, with the selection based on the Hausman test results. When the result produces a probability value below 0.05 , use FEM, and when it is above 0.05 , use the REM model. Furthermore, the FEM or REM test results are arranged in a path analysis to determine the direct and indirect effects of the model developed. Before testing the hypothesis, this study carried out the data normality and the correlation between independent variables (multicollinearity).

SSB expertise in economics, finance, and accounting (SSB Expert) is measured from the member percentages that have taken these courses at the undergraduate, master, and doctorate levels. The financing variable is measured by the ratio of distributed funds by banks to the total assets, while third party funds are measured by the percentage of Investment Account Holders (IAH) to total assets. The profitability variable is measured by Return on Assets (ROA), from the ratio of net income to total assets. In all model tests, this study also uses the amount of assets as a control variable.

\section{RESULTS AND DISCUSSION}

In the initial stages of data testing, this study presents a variable description to determine the data distribution, as presented in table 1 . The descriptive variable shows that Islamic banks in Indonesia have a less diverse number of SSB members, which is between 2-3 people. This is in accordance with the rules of the FSA that Sharia banks are required to have a minimum SSB of 2 members and a maximum of $50 \%$ of the total number of boards. The profile of SSB's economics, finance, and accounting expertise is still very limited, with an average of $20.39 \%$. Table 1 also shows there are SSB samples without expertise in these regions. 
Table 1: Descriptive variables

\begin{tabular}{lcccccc}
\hline & SSB Size & SSB Expert & Financing & IAH & ROA & Ln. Assets \\
\hline Mean & 2.485437 & 0.203883 & 0.687845 & 0.704529 & 0.008692 & 29.72166 \\
Median & 2.000000 & 0.000000 & 0.701870 & 0.722665 & 0.008000 & 29.58182 \\
Maximum & 3.000000 & 0.666667 & 0.890382 & 0.894679 & 0.124000 & 32.21946 \\
Minimum & 2.000000 & 0.000000 & 0.280965 & 0.099841 & -0.201300 & 26.85169 \\
Std. Dev. & 0.502232 & 0.244695 & 0.089909 & 0.138227 & 0.033574 & 1.254172 \\
Skewness & 0.058277 & 0.618146 & -1.510965 & -1.739264 & -2.237519 & 0.195993 \\
Kurtosis & 1.003396 & 1.852895 & 7.296263 & 7.505121 & 20.21066 & 2.225964 \\
Observations & 103 & 103 & 103 & 103 & 103 & 103 \\
\hline
\end{tabular}

The sample has an average financing and IAH ratio of $68.78 \%$ and $70.45 \%$, respectively. This proves that Islamic banks have a fairly good intermediary function. Approximately $68.78 \%$ of funds collected from customers have been distributed in the form of financing, with the remaining $1.67 \%$ used for liquidity. The level of profitability measured by ROA has an average value of $0.86 \%$. The minimum ROA value of $-20.31 \%$ showed that some Islamic banks suffer losses.

The correlation test between shows no multicollinearity test between independent variables below 0.80 .

Table 2: Multicollinearity Test Between Independent Variables

\begin{tabular}{llllll}
\hline & & SSB Size & SSB Expert & Financing & IAH \\
\hline SSB & Size & 1 & 0.6239 & 0.3001 & 0.2640 \\
SSB Expert & 0.6240 & 1 & 0.1384 & 0.2766 \\
Financing & 0.3001 & 0.13837 & 1 & 0.1934 \\
\hline IAH & 0.2640 & 0.2766 & 0.1934 & 1 \\
\hline
\end{tabular}

The next step is to test the hypothesis model. Test results using FEM and REM are shown in table 3.

Table 3: Model Test Results

\begin{tabular}{lcccccc}
\hline \multirow{2}{*}{$\begin{array}{l}\text { Independent } \\
\text { Variables }\end{array}$} & \multicolumn{2}{c}{ Financing } & \multicolumn{2}{c}{ IAH } & \multicolumn{2}{c}{ ROA } \\
\cline { 2 - 7 } SSB Size & Coeff & t-Statistic & Coeff & t-Statistic & Coeff & t-Statistic \\
SSB Expert & $0.0728^{* *}$ & 2.4192 & 0.0227 & 0.4772 & -0.000421 & -0.0337 \\
Financing & $-0.1372 * *$ & 2.3796 & -0.0185 & 0.2341 & 0.011256 & 0.4969 \\
IAH & - & - & - & - & $-0.0923 * *$ & -2.6132 \\
Control Variable & - & - & - & - & $-0.0758^{* *}$ & -2.5150 \\
Assets & $-0.0260^{* *}$ & 2.5507 & $0.0252^{*}$ & 1.6820 & 0.0055 & - \\
Adjusted R & & 0.1118 & & 0.0013 & & 0.1189 \\
F-Statistic & & 5.3619 & & 1.0451 & & 3.7788 \\
Probability & & 0.0018 & & 0.3761 & & 0.0036 \\
\hline
\end{tabular}

$* * *$ Significant at $1 \% ; * * 5 \% ; * 10 \%$ 
Table 2 shows that the total SBB members has a positive effect on financing, and does not affect the amount of IAH funds. This research shows that SSB provides more consulting services on financing products compared to funding (ceteris paribus). This is due to the numerous contracts or transactions renewal on financing products. Furthermore, financing is one of the main and risky products of banks (Abedifar, Molyneux, \& Tarazi, 2013). Therefore, adequate supervision is needed in adherence to sharia laws.

SSB's expertise in economics, finance, and accounting has a negative and significant effect on financing and none on IAH funds. These results contradict the test results obtained from the total SBB members. These results indicate that SSB with expertise in economics encourages banks to be careful in distributing finance. The allegation is associated with high Islamic banks NPF in Indonesia(Mustafidah \& Mukhibad, 2018), which further reduces ROA (Mukhibad \& Khafid, 2018). In distributing financing, banks are more concerned with the advice of SSB experts in economics, finance, and accounting than in non-economic fields. However, this does not mean that Shariah compliance aspects are ignored in distributing finance as the bank's main source of income(Abusharbeh, 2014; Abedifar et al., 2013).

The results also showed that the amount of financing has a negative effect on ROA due to the high bank NPF. According to Abusharbeh (2014) also Kinanti and Purwohandoko (2017), an increase in funding leads to a rise in NPF, which further reduces ROA (Kinanti \& Purwohandoko, 2017; Yusuf, 2017). Financing is the main source of bank income, therefore, the absence of barriers leads to a rise in financial growth(Fowowe, 2017).

The effect test results show that the ratio of third-party funds has a negative effect on ROA. This means that the additional ratio reduces ROA and increases deposit funds with a decrease in income due to the possibility of banks to distribute more profitable financing. A feasibility analysis is needed in distributing the funds raised and eliminating the negative impact on profits. However, undistributed IAH funds burdens mudharabah per-fund income received by bank and subsequently increases the amount of profit-sharing costs provided by the bank to customers and reduce profit-sharing income as a bank right.

Conversely, Almutairi and Quttainah (2017); Nomran and Haron (2019); and Nomran et al. (2018) stated that there is a significant relationship between the total SBB members on ROA, ROE, and Tobin Q. However, this study is in accordance with Hakimi et al. (2018); Ardana (2019); also Mollah and Zaman (2015). It also supports the allegation that the total SBB members do not have a direct impact on profitability. This is because the SSB is tasked with the consideration or assessment of Shariah compliance on existing transactions at banks, which is carried out following Sharia. Law number 21 of 2008 explains that SSB provides advice and recommendation to Directors and in supervising the Bank activities to be in accordance with Sharia Principles. 


\section{Path Analysis}

The next step is to carry out a path analysis to provide empirical evidence that SSB has an indirect effect on ROA. Therefore, based on the test results shown in table 2, the path analysis is arranged as follows:

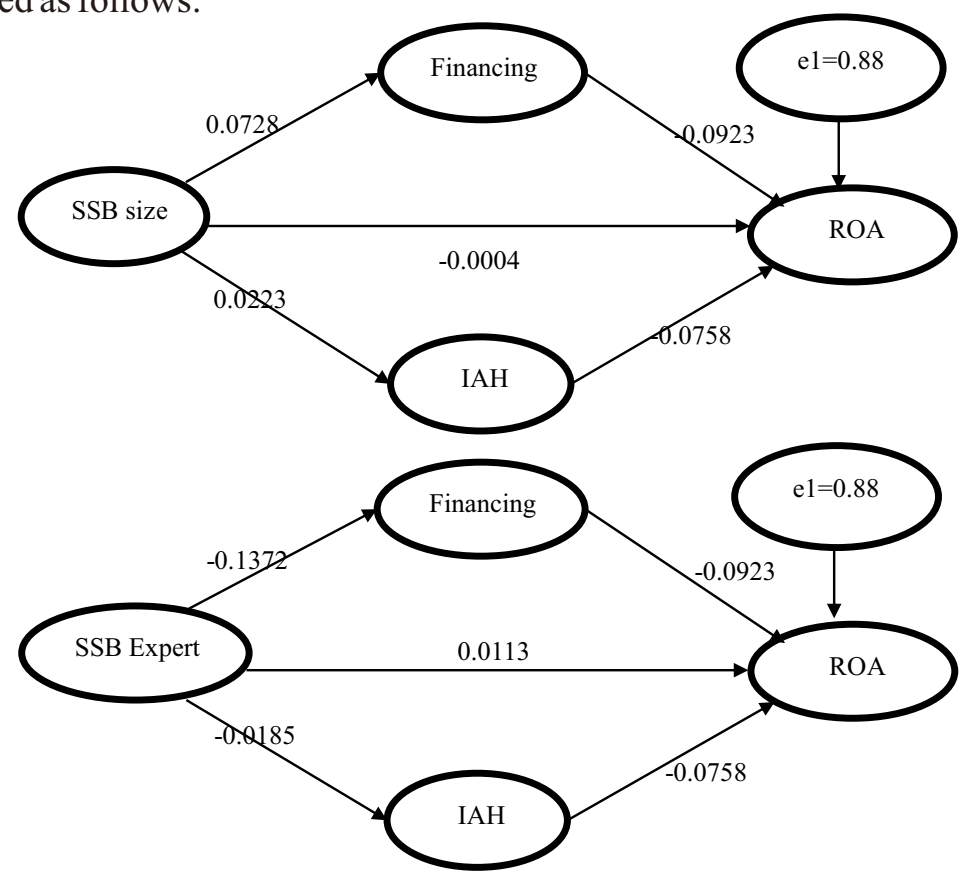

Figure 1. The Path Analysis Results

Figure 1a shows that the total SBB members have a direct effect of -0.0004 towards ROA. Furthermore, the total SBB members have a direct impact on the financing and ROA ratios of 0.0728 , and -0.0923 . Therefore, it can be determined that the total SBB members have an indirect effect through the financing ratio of 0.0067 . This indirect effect is greater than the direct effect of $-0,0004$, which shows that the total SBB members has an indirect impact on ROA.

Figure 1a shows that the total SBB members have an effect of 0.0223 on IAH and ROA of -0.0758 . The indirect effect from the total members of SBB members with ROA is -0.0017 and greater than $-0,0004$. This reinforces previous findings that the total SBB members are shown to have an indirect effect on ROA through IAH funds, and greater than the direct effect between the total SBB members and ROA.

Figure 1b explains the direct and indirect effect between SSB's expertise in economics, finance, and accounting towards ROA. This study found that SSB's expertise had a direct effect of 0.0113 and -0.1372 towards the amount of financing. It also has a direct effect on ROA of 0.0923. The indirect effect of SSB expertise on ROA is 0.01266 . These results indicate that SSB expertise has an indirect effect greater than the indirect effect towards ROA. This finding led to the decision to accept the hypothesis developed, namely financing becomes the mediating variable on the relationship between SSB's expertise towards ROA. 
Figure 1b shows that SSB expertise has a direct effect towards IAH funds of -0.0185 and ROA of -0.0758 . The total direct effect of SSB expertise towards ROA through IAH funds is 0.001402. When compared, it shows that SSB expertise has a greater direct effect. This means that the IAH fund is not a mediating variable between SSB's expertise towards ROA.

\section{Robustness Check}

Based on the stages of robustness check testing, this study uses the Ordinary Least Square (OLS) method to reinforce the research results described previously. The OLS test shown in table 5 reinforces previous findings that the total SBB members have a positive effect on the amount of financing, with no effect on IAH funds. Furthermore, the total SBB members also proved to have no effect on ROA. SSB expertise in economics, finance, and accounting has a negative effect on the amount of financing and does not affect IAH funds and ROA. Financing and IAH funds are proven to have a negative effect on ROA. Based on these findings, all these robustness tests reinforce the research results.

Table 4. Model Test Results by using Ordinary Least Square (Robustness Check)

\begin{tabular}{lcccccc}
\hline \multicolumn{1}{c}{ Independent } & \multicolumn{2}{c}{ Financing } & \multicolumn{2}{c}{ IAH } & \multicolumn{2}{c}{ ROA } \\
\cline { 2 - 7 } \multicolumn{1}{c}{ Variables } & Coeff & t-Statistic & Coeff & t-Statistic & Coeff & t-Statistic \\
\hline SSB Size & $0.067^{* * *}$ & 2.7028 & 0.0085 & 0.2515 & -0.0035 & -0.4109 \\
SSB Expert & $-0.1067^{* *}$ & -2.1278 & 0.0635 & 0.9418 & 0.0062 & 0.3640 \\
Financing & - & - & - & - & $-0.0985^{* *}$ & -2.6419 \\
IAH & - & - & - & - & $-0.0522^{*}$ & -2.0892 \\
Control Variable & - & - & - & - & & \\
Assets & $0.0201^{* *}$ & 2.2622 & 0.0362 & $3.0670 * * *$ & $0.0077^{*}$ & 2.4990 \\
Adjusted R & & 0.1365 & & 0.1435 & & 0.0951 \\
F-Statistic & & 6.4816 & & 6.751 & & 3.164 \\
Probability & & 0.0005 & & 0.0003 & & 0.0109 \\
\hline
\end{tabular}

$* * *$ Significant at $1 \% ; * * 5 \% ; * 10 \%$

The results of direct and indirect effects test also confirm the previous results. The direct effect on the total SBB members towards ROA is -0.0035 , while the indirect effect through the amount of financing is -0.0069 . Therefore, the indirect effect is greater than the direct effect. SSB expertise has a direct effect on ROA of 0.0062 while having an indirect effect on ROA through the amount of financing of 0.0105 . These results reinforce these research findings that the amount of SSB has an indirect effect on ROA through financing. This means that the services provided by SSB towards financing products have an effect on ROA.

The indirect effect on the total SBB members towards ROA through IAH funds produced a coefficient of -0.00044 , which is lower than the direct effect on the total SBB member with ROA of -0.0035 . The indirect effect on SSB expertise towards ROA through produced a coefficient of -0.0033 , and this value is lower than the direct effect on SSB expertise with ROA of 0.0062 . These two tests reinforce this research results that IAH funds are not proven to be a mediating variable between the total SBB members and SSB expertise towards ROA. 


\section{CONCLUSION}

Previous studies show the inconsistency associated with the presence or absence of SSB attributes and profitability needs to obtain a deeper explanation. This study indirectly analyzes the relationship between SSB and profitability. This is because the SSB functions as an independent board that provides consulting and supervision services for products owned by banks. Therefore, the relationship between SSB and ROA is mediated by financing products and IAH funds.

These results showed that ROA is negatively and significantly affected by finance and IAH funds. The total SSB members have a positive relationship with financing and SSB's expertise with a negative effect on IAH funds. Furthermore, the total SBB members and expertise in economics, finance, and accounting fields have no relationship with ROA.

The path analysis results showed that financing is a mediating relationship between the total SBB members towards ROA. Financing also mediates the relationship between SSB's expertise towards ROA. Furthermore, the IAH fund is a mediating variable on the effect between the total SBB members towards ROA. This means that consulting and supervision services carried out by SSB towards the implementation of financing and fundraising products have an impact on banks' ability to distribute finance and raise funds from customers, which tends to have a positive impact on profitability. Products offered by banks need to obtain approval from SSB, which tends to affect the banks' ability to offer their products to customers.

This research is based on the rules of sharia bank regulators in Indonesia, limiting the SSB's duties to supervise and guarantee products owned by banks. In other countries, SSB can have broader duties than in Indonesia. Therefore, future studies on those using Islamic banks in other countries as objects of study need to pay attention to the SSB duties that differ between countries. Furthermore, this study only uses the two main bank products and ignores the services provided by banks. Further, studies need to use bank service products as a mediating variable between SSB and profitability.

\section{BIBLIOGRAPHY}

Abedifar, P., Molyneux, P., \& Tarazi, A. (2013). Risk in Islamic Banking. Review of Finance, 17(6), 20352096. https://doi.org/10.1093/rof/rfs041.

Abusharbeh, M. T. (2014). CreditRisks and Profitability of Islamic Banks: Evidence from Indonesia. World Review of Business Research, 4(3), 136147.

Almutairi,A. R., \& Quttainah, M.A. (2017). Corporate Governance: Evidence from Islamic Banks. Social Responsibility Journal, 13(3), 601624. https://doi.org/10.1108/SRJ-052016-0061. 
Almutairi, A. R., \& Quttainah, M. A. (2017). Corporate Governance: Evidence from Islamic Banks. Social Responsibility Journal, 13(3), 601-624. https://doi.org/10.1108/SRJ-05 2016-0061. Alsartawi, A. M. (2019). Performance of Islamic Banks: Do the Frequency of Sharī ah Supervisory Board Meetings and Independence Matter?. ISRA International Journal of Islamic Finance, 11(2), 303-321. https://doi.org/10.1108/ijif-05-2018-0054.

Ardana, Y. (2019). Implementasi Good Corporate Governance(GCG) dalam Mengukur Risiko dan Kinerja Keuangan Bank Syariah di Indonesia. Jurnal Masharif Al-Syariah: Jurnal Ekonomi dan Perbankan Syariah, 4(1), 97-112. DOI: http://dx.doi.org/10.30651/jms. v4i1.2587.

Dang, V. D. (2019). The Effects of Loan Growth on Bank Performance: Evidence from Vietnam. Management Science Letters, 9(6), 899-910.https://doi.org/10.5267/j.ms1.2019.2.012. Dignah, A., Latiff, R. A., \& Rahman, A. A. (2012). Islamic Banks' Risk, Profitability and Risk Disclosure. Afro-Asian Journal of Finance and Accounting, 3(2), 105-120. https://doi.org/ 10.1504/AAJFA.2012.048240.

Farag, H., Mallin, C., \& Ow-Yong, K. (2014). Corporate Social Responsibility and Financial Performance in Islamic Banks. Journal of Economic Behavior and Organization, 103. https://doi.org/10.1016/j.jebo.2014.03.001

Farag, H., Mallin, C., \& Ow-Yong, K. (2018). Corporate Governance in Islamic Banks: New Insights for Dual Board Structure and Agency Relationships. Journal of International Financial Markets, Institutions and Money, 54, 59-77. https://doi.org/10.1016/j.intfin.2017.08.002.

Farook, S., Hassan, M, K., \& Lanis, R. (2011). Determinants of Corporate Social Responsibility Disclosure: The Case of Islamic Banks. Journal of Islamic Accounting and Business Research, 2(2), 114-141. https://doi.org/10.1108/17590811111170539.

Fitriyah, F., \& Oktaviana, U. O. (2007). Relevance of Financial Performance and Good Corporate Governance Determinant of Sustainaibility Corporate Social Responsibility Disclousure in Islamic Bank in Indonesia. International Journal of Nusantara Islam, 1(2), 22-37.

Fowowe, B. (2017). Access to Finance and Firm Performance: Evidence from African Countries. Review of Development Finance, 7(1), 6-17. https://doi.org/10.1016/j.rdf.2017.01.006.

Garas, S. N. (2010). The Role of the Shari'a Supervisory Board in the Governance of Islamic Financial Institutions in the Gulf Cooperation Council Countries. Corporate Ownership and Control, $8(1), 247-266$.

Ghayad, R. (2008). Corporate Governance and the Global Performance of Islamic Banks. Humanomics, 24(3), 207-216. https://doi.org/10.1108/08288660810899368.

Grassa, R., \& Matoussi, H. (2014). Is Corporate Governance Different For Islamic Banks? A 
Comparative Analysis Between the Gulf Cooperation Council Context and the Southeast Asia Context. International Journal Business Governance and Ethics, 9(1), 27-51, DOI: 10.1504/IJBGE.2014.062769.

Grassa, R. (2016). Corporate Governance and Credit Rating in Islamic Banks: Does Shariah Governance Matters ? Journal of Management \& Governance, 20(4), 875-906. https: //doi.org/10.1007/s10997-015-9322-4.

Hakimi, A., Rachdi, H., Mokni, R. B. S., \& Hssini, H. (2018). Do Board Characteristics Affect Bank Performance? Evidence from the Bahrain Islamic Banks. Journal of Islamic Accounting and Business Research, 9(2), 251-272. https://doi.org/10.1108/JIABR06-2015-0029.

Hamdi, F. M., \& Zarai, M. A. (2014). Corporate Governance Practices and Earnings Management in Islamic Banking Institutions. Research Journal of Finance and Accounting, 5(9), 2222-2847.

Indrawaty, \& Wardayati, S. M. (2016). Implementing Islamic Corporate Governance (ICG) and Islamic Social Reporting (ISR) in Islamic Financial Institution(IFI). Procedia - Social and Behavioral Sciences, 219, 338-343. https://doi.org/10.1016/j.sbspro.2016.04.042.

Kassem, N. M., \& Sakr, A. (2018). The Impact of Bank-Specific Characteristics on the Profitability of Commercial Banks in Egypt. Journal of Finance and Bank Management, 6(2), 76-90.https://doi.org/10.15640/jfbm.v6n2a8.

Kinanti, A. R., \& Purwohandoko, P. (2017). Influence of Third-Party Funds, CAR, NFP and FDR Towards the Return on Assets of Islamic Banks in Indonesia. JEMA: Jurnal Ilmiah Bidang Akuntansi dan Manajemen, 14(02), 135-143. https://doi.org/10.31106/jema.v14i02.524.

Mersni, H., \& Othman, H. B. (2016). The Impact of Corporate Governance Mechanisms on Earnings Management in Islamic Banks in the Middle East Region. Journal of Islamic Accounting and Business Research, 7(4), 318-348. https://doi.org/10.1108/JIABR-112014-0039.

Mohammed, S. A. S. A. N., \& Muhammed, J. (2017). The Relationship between Agency Theory, Stakeholder Theory and Shariah Supervisory Board in Islamic Banking: An Attempt towards Discussion. Humanomics, 33(1), 75-83. https://doi.org/10.1108/H08-2016-0062.

Mollah, S., \& Zaman, M. (2015). Shari'ah Supervision, Corporate Governance and Performance: Conventional vs Islamic Banks. Journal of Banking \& Finance, 58, 418-435. https://doi.org/10.1016/j.jbankfin.2015.04.030. 
Mukhibad, H., \& Khafid, M. (2018). Financial Performance Determinant of Islamic Banking in Indonesia. Jurnal Keuangan dan Perbankan, 22(3), 506-517. DOI: https://doi.org/10. 26905/jkdp.v22i3.2061.

Mustafidah, U., \& Mukhibad, H. (2018). Jenis Pembiayaan, Corporate Governance, Human Capital Investment dan Implikasinya Terhadap Non Performing Financing. Simposium Nasional Akuntansi, (21), 1-16.

Neifar, S., \& Jarboui, A. (2018). Research in International Business and Finance Corporate Governance and Operational Risk Voluntary Disclosure: Evidence from Islamic Banks. Research in International Business and Finance, 46(146), 43-54. https://doi.org/10.1016/j.ribaf. 2017.09.006.

Nomran, N. M., Haron, R., \& Hassan, R. (2018). Shari'ah Supervisory Board Characteristics Effects on Islamic Banks' Performance: Evidence from Malaysia. International Journal of Bank Marketing, 36(2), 290-304. https://doi.org/10.1108/IJBM-12-2016-0197.

Nomran, N. M., \& Haron, R. (2019). Dual Board Governance Structure and Multi-bank Performance: A Comparative Analysis between Islamic Banks in Southeast Asia and GCC Countries. Corporate Governance, 19(6), 1377-1402.https://doi.org/10.1108/CG-10-2018-0329.

Nomran, N. M., \& Haron, R. (2020). Shari'ah Supervisory Board's Size Impact on Performance in the Islamic Banking Industry: An Empirical Investigation of the Optimal Board Size Across Jurisdictions. Journal of Islamic Accounting and Business Research, 11(1), 110-129. https://doi.org/10.1108/JIABR-05-2017-0070.

Rahayu, R., Rasyid, S., \& Sabir. (2019). The Effect of Sharia Supervisory Board on Financial Performance, with Islamic Social Reporting as the Intervening Variable. Quest: Journal of Research in Business and Management, 7(1), 69-72.

Rahman, A. A., \& Bukair, A. A. (2013). The Influence of the Shariah Supervision Board on Corporate Social Responsibility Disclosure by Islamic Banks of Gulf Co-Operation Council Countries. Asian Journal of Business and Accounting, 6(2), 65-104. https://doi.org/10.5296/jmr.v7i2.6989

Sari, Y.A. N., \& Murni, N. S. I. M. (2016). Analysis of the Effect of Third Party Fund, Capital Adequacy Ratio, and Loan to Deposit Ratio on Bank's Profitability after the Application of IFRS. The Indonesian Accounting Review, 6(1), 81-90. https://doi.org/10.14414/tiar. v6i1.855.

Srairi, S. (2018). Determinants of Corporate Risk Disclosure Practices: the Case of Islamic Banks in Gulf Cooperation Council Region. The Journal of Muamalat and Islamic Finance Research,15(1), 21-50. DOI:10.33102/jmifr.v15i1.99. 
Wang, R., \& Wang, X. (2014). What Determines The Profitability of Banks? Evidence From The Us. Graduating Extended Essay. Simon Fraser University.

Yusuf, M. (2017). Dampak Indikator Rasio Keuangan terhadap Profitabilitas Bank Umum Syariah di Indonesia. Jurnal Keuangan dan Perbankan, 13(2), 141-151. 